\section{Time of Flooding and Cultivar Affect Sweetpotato Yield}

\author{
Warren Roberts \\ Wes Watkins Agricultural Research and Extension Center, Oklahoma \\ State University, Box 128, Lane, OK 74555
}

\author{
Vincent Russo \\ U.S. Department of Agriculture, Agricultural Research Service, Box 159, \\ Lane, $O K 74555$
}

Additional index words. Ipomoea batatas, water-logging

\begin{abstract}
The sweetpotato [ Ipomoea batatas (L.) Lam] cultivars Jewel, Shore Gold, and Cordner, and the breeding line W241 were either 1) not flooded, 2) flooded for 5 days during midseason, or 3 ) flooded for 5 days just before harvest. Flooding just before harvest did not affect marketable yield, but flooding at midseason reduced marketable yield by $36 \%$ in 1989 and by $53 \%$ in 1990 and reduced the No. 1 grade yield by $46 \%$ in 1989 and by $57 \%$ in 1990 . Marketable yield of 'Jewel' was higher than that of 'Cordner' in 1989, and that of 'Shore Gold' exceeded that of 'Jewel' in 1990. There were no interactions between flooding treatments and cultivars.
\end{abstract}

Sweetpotato production in the United States is located primarily in the southeastern and south-central states. This area has abundant rainfall, and the soil can become saturated at any time. Hurricanes and strong storms that strike the Atlantic and Gulf Coast states can flood sweetpotato fields, causing serious problems to producers. Kushman et al. (1954, $1958,1959)$ reported that storage quality of 'Porto Rico' and 'Centennial' sweetpotato roots was adversely affected by excessively high soil moisture before harvest. Ton and Henandez (1978) found that sweetpotatoes flooded for $72 \mathrm{~h}$ before harvest had more rot at harvest and increased shrinkage loss in storage than did nonflooded roots. Although flooding did not significantly affect total yield, there were differences among cultivars in the amount of rot at harvest and during curing. Ahn et al. (1980) found that four genotypes of sweetpotatoes exposed to 1 week of warm flooding ( 24 to $34 \mathrm{C}$ ) exhibited more root rotting during curing and storage than did sweetpotatoes exposed to cold flooding (4C), cold dry soil, or warm dry soil. Postharvest storage rot incidence was not affected by genotype. Collins and Wilson (1988) found that damage to sweetpotatoes flooded in 1984 depended on the cultivar, with the percentage of flood-damaged roots varying from $0.2 \%$ to $38 \%$ of the total harvested roots. There was little additional root rot during storage.

In the previous studies, flooding just before harvest did not affect yield, but various

\footnotetext{
Received for publication 22 Apr. 1991. Journal article no. 5996 of the Agricultural Experiment Station, Oklahoma State Univ.. Stillwater. Research conducted by the Dept. of Horticulture and Landscape Architecture in cooperation with the USDA-ARS. We are indebted to C.W. O'Hern and T.D. Abney for technical assistance. The cost of publishing this paper was defrayed in part by the payment of page charges. Under postal regulations, this paper therefore must be hereby marked advertisement solely to indicate this fact.
}

cultivars responded differently to flooding with respect to curing and storage. There is no information on how flooding earlier in the season affects yield. This study was designed to examine the effects of flooding at two times during production on the yield of three sweetpotato cultivars.

The experiment was conducted in 1989 and 1990 on a Bernow fine-loamy, siliceous, thermic Glossic Paleudalf soil. The A horizon is a fine sandy loam, $\approx 30$ to $35 \mathrm{~cm}$ deep, with a percolation rate of 5.1 to 15.2 $\mathrm{cm} \cdot \mathrm{h}^{-1}$. The B horizon is a sandy clay loam, 125 to $165 \mathrm{~cm}$ deep, with a percolation rate of 1.5 to $5.1 \mathrm{~cm} \cdot \mathrm{h}^{-1}$. Since percolation rates of these horizons differ, total drainage is limited by the B horizon, and water can collect above it.

The study was arranged in a split-plot design with four replications. Flooding treatments were the main plots and cultivars were the subplots. Flooding treatments included a control (no flooding), flooding half-way through the growing season $(\approx 60$ days after planting), and flooding just before harvest $(\approx 113$ days after planting). 'Jewel', 'Shore Gold', 'Cordner', and the breeding line W241 (U.S. Vegetable Laboratory, Charleston, S.C.) were used each year.

Main plots, $4.6 \mathrm{~m}$ long $\times 8 \mathrm{~m}$ wide, contained eight rows on 1-m centers and were separated lengthwise by $3-\mathrm{m}$ alleys. Individual rows were bedded, each bed was $\approx 0.3$ $\mathrm{m}$ wide and $0.3 \mathrm{~m}$ tall. Plants were spaced $0.3 \mathrm{~m}$ apart in each row. The outer two rows (rows 1 and 8 ) in each main plot were left unplanted, rows 2 and 7 were planted as guard rows, and rows $3,4,5$, and 6 each received one cultivar per row.

Slips, obtained from roots bedded locally, were transplanted on 1 June 1989 and 8 June 1990. Fertilizer was applied preplant at $\left(\mathrm{kg} \cdot \mathrm{ha}^{-1}\right) 56 \mathrm{~N}, 62 \mathrm{P}$, and $154 \mathrm{~K}$ from a $9 \mathrm{~N}-$ $10 \mathrm{P}-25 \mathrm{~K}$ blend. Midseason flooding was imposed 7-11 Aug. 1989 and 30 July-3 Aug. 1990; late-season flooding was imposed 25-
29 Sept. 1989 and 24-28 Sept. 1990.

Earthen dams were formed at both ends of the plots to facilitate flooding. Water was directed into the alleys between rows through 3.8-cm-diameter irrigation laterals. Flooding was maintained so that water levels were kept at or near the top of each raised bed, with water $\approx 0.3 \mathrm{~m}$ deep in the alleys. Flooding was maintained for 5 days on the central six rows in each eight-row main plot. All four subplot rows (rows 3 to 6) and the two adjacent guard rows (rows 2 and 7) were flooded. There were two nonflooded, nonplanted guard rows (rows 1 and 8 ) between adjacent main plots. Tensiometers were used to monitor soil moisture tension in all treatments and to verify that flooding was maintained at the rooting level $(20 \mathrm{~cm}$ depth) in the appropriate plots.

Harvests were on 13 Oct. 1989 and 22 Oct. 1990. Sweetpotato storage roots were graded and weights were recorded according to the following classifications: canners $(2.5$ to $5.1 \mathrm{~cm}$ in diameter, 5.1 to $17.8 \mathrm{~cm}$ long); no. 1 ( 5.1 to $8.9 \mathrm{~cm}$ in diameter, 7.6 to 22.9 $\mathrm{cm}$ long); Jumbo (>8.9 $\mathrm{cm}$ in diameter, $>22.9 \mathrm{~cm}$ long); culls $(>2.5 \mathrm{~cm}$ in diameter and misshapen or showing signs of decay). All roots $<2.5 \mathrm{~cm}$ in diameter were discarded without being graded.The number of roots culled because of rots, cracks, or misshapen roots was determined. For data analyses, weights of canners, no. 1s, and jumbos were numerically combined into a "marketable" category.

Yield from plots flooded in late season was similar to yield of the nonflooded controls (Table 1). However, in both years, marketable and total yields for the midseason-flooded plants were significantly lower than yields from nonflooded or late-seasonflooded plants. In 1989, differences occurred primarily with no. 1 and canner grades, and in 1990 with no. 1 and jumbo roots. The marketable yield of 'Jewel' was higher than that of 'Cordner', and the total yields of both 'Jewel' and 'Shore Gold' were higher than that of 'Cordner'. 'Shore Gold' produced the highest total yield, primarily because of high yield in the jumbo category. There were no interactions between flooding treatments and cultivars in either year, but midseason flooding reduced the yield of all cultivars (interaction data not shown). When all cultivars were averaged, midseason flooding reduced the marketable yield by $36 \%$ in 1989 and by $53 \%$ in 1990 relative to the nonflooded control.

In 1989 , culls made up $\approx 16 \%$ of total yield. In that year, midseason flooding produced $23 \%$ culls vs. $12 \%$ for late-season flooding and $15 \%$ for controls. In 1990, culls made up $\approx 52 \%$ of total yield. The percentage of culls in 1990 was generally unaffected by treatment, with midseason flooding producing $54 \%$ culls vs. $49 \%$ for late-season flooding and $53 \%$ for the nonflooded control. The number of cull roots categorized by cause (rots, cracks, or misshapen roots) was not significantly affected by treatment or cultivar.

Precipitation was $1010 \mathrm{~mm}$ in 1989 and $1830 \mathrm{~mm}$ in 1990. During the sweetpotato 
Table 1. Effect of flooding, time of flooding, and cultivar on yield of sweetpotatoes.

\begin{tabular}{|c|c|c|c|c|c|c|c|c|c|c|c|c|}
\hline \multicolumn{13}{|c|}{ Yield $\left(\mathrm{Mg} \cdot \mathrm{ha}^{-1}\right)^{\mathrm{z}}$} \\
\hline \multirow[b]{2}{*}{ Variable } & \multicolumn{6}{|c|}{1989} & \multicolumn{3}{|c|}{ + } & \multicolumn{3}{|l|}{1990} \\
\hline & Canner & No. 1 & Jumbo & Cull & Marketable $^{\mathbf{x}}$ & Total & Canner & No. 1 & Jumbo & Cull & Marketable ${ }^{\mathbf{x}}$ & Total \\
\hline \multicolumn{13}{|l|}{ Flooding } \\
\hline None & $4.11 \mathrm{a}^{\mathrm{y}}$ & $6.68 \mathrm{a}$ & $2.46 \mathrm{a}$ & $2.41 \mathrm{a}$ & $13.25 \mathrm{a}$ & $15.66 \mathrm{a}$ & $0.79 \mathrm{a}$ & 6.12 a & $2.25 \mathrm{ab}$ & $10.46 \mathrm{a}$ & $9.16 \mathrm{a}$ & $19.62 \mathrm{a}$ \\
\hline Late-season & $3.96 \mathrm{a}$ & $6.33 \mathrm{a}$ & $2.89 \mathrm{a}$ & $1.79 \mathrm{a}$ & $13.19 \mathrm{a}$ & 14.97 a & $1.28 \mathrm{a}$ & $5.65 \mathrm{a}$ & $5.08 \mathrm{a}$ & $11.55 \mathrm{a}$ & $12.01 \mathrm{a}$ & 23.56 a \\
\hline Midseason & $2.53 \mathrm{~b}$ & $3.64 \mathrm{~b}$ & $2.30 \mathrm{a}$ & $2.60 \mathrm{a}$ & $8.47 \mathrm{~b}$ & $11.07 \mathrm{~b}$ & $0.76 \mathrm{a}$ & $2.61 \mathrm{~b}$ & $0.96 \mathrm{~b}$ & $5.07 \mathrm{~b}$ & $4.33 \mathrm{~b}$ & $9.40 \mathrm{~b}$ \\
\hline \multicolumn{13}{|l|}{ Cultivar } \\
\hline Jewel & $3.28 \mathrm{~b}$ & 7.44 a & $3.58 \mathrm{ab}$ & $2.18 \mathrm{~b}$ & $14.28 \mathrm{a}$ & $16.46 \mathrm{a}$ & $1.05 \mathrm{a}$ & 4.15 a & $1.12 \mathrm{~b}$ & 9.68 a & $6.33 \mathrm{~b}$ & $16.00 \mathrm{~b}$ \\
\hline Shore Gold & $2.28 \mathrm{~b}$ & $4.81 \mathrm{~b}$ & $4.10 \mathrm{a}$ & $4.03 \mathrm{a}$ & $11.19 \mathrm{ab}$ & $15.23 \mathrm{a}$ & $0.80 \mathrm{a}$ & $5.66 \mathrm{a}$ & $5.71 \mathrm{a}$ & 10.73 a & $12.18 \mathrm{a}$ & $22.90 \mathrm{a}$ \\
\hline Cordner & $2.54 \mathrm{~b}$ & $3.97 \mathrm{~b}$ & $2.14 \mathrm{bc}$ & $1.91 \mathrm{~b}$ & $8.65 \mathrm{~b}$ & $10.56 \mathrm{~b}$ & $1.36 \mathrm{a}$ & $5.01 \mathrm{a}$ & $1.66 \mathrm{~b}$ & 8.15 a & $8.04 \mathrm{ab}$ & $16.19 \mathrm{~b}$ \\
\hline W241 & $6.02 \mathrm{a}$ & $6.08 \mathrm{ab}$ & $0.54 \mathrm{c}$ & $1.05 \mathrm{~b}$ & $12.64 \mathrm{ab}$ & $13.69 \mathrm{ab}$ & $0.58 \mathrm{a}$ & $4.33 \mathrm{a}$ & $2.55 \mathrm{ab}$ & $7.56 \mathrm{a}$ & $7.46 \mathrm{ab}$ & $15.01 \mathrm{~b}$ \\
\hline
\end{tabular}

$z$ The flooding $\times$ cultivar interaction was not significant for any variable.

yMean separation by Duncan's multiple range test, $P=0.05$.

×Sum of Canner, No. 1, and Jumbo categories.

growing season (June-October) in 1989 and 1990, rainfall amounts were 510 and 560 mm. In one 5-day period in Sept. 1989, there was $174 \mathrm{~mm}$ of rainfall, and in a 5-day period in Sept. 1990, there was $207 \mathrm{~mm}$ of rainfall. Soil in all plots was at times saturated in the furrows, but not at the top of the raised beds. The 5-day duration of natural rainfall was similar to the duration of imposed flooding, but surface drainage was sufficient to prevent ponding of water above the surface of the furrow. Total yield in all treatments was low, and the percentage of culls was high, possibly because of the wet soil. There was an additional substantial reduction in yield with the plots flooded at midseason, but not at late season.

The reduction in final yield caused by midseason flooding appears to have been caused by the loss, presumably due to rot, of the existing storage roots. This position is supported by the tremendous reduction in U.S. no. $1 \mathrm{~s}$ and jumbo roots in 1990, suggesting that the storage roots present at harvest were either sufficiently small during the stress period and/or were induced following flooding.

The lack of a yield response from late- season flooding is consistent with other experimental reports. Our research shows that flooding at midseason in 1989 and 1990 resulted in a $36 \%$ and $53 \%$ reduction in marketable yield. The no. 1 grade, which normally has the highest value per unit, had a yield reduction from midseason flooding of $46 \%$ and $57 \%$ in 1989 and 1990, respectively. These yield reductions would have drastically reduced the economic return to the producer.

Late-season flooding has been shown to have detrimental effects on storage quality of sweetpotato roots. Although late-season flooding in this study did not reduce yield of marketable roots at harvest, the quality of roots following storage, which we did not evaluate for any treatment, could have been affected. Thus, the final effects of late-season flooding could be more detrimental than was shown here. Cultivars differed in yield, independent of flooding.

The amount of flooding imposed was extreme, but could occur under natural conditions. Additional research is needed to determine how much flooding, for how long, at midseason or at other times of the year would detrimentally affect yield of various cultivars.

\section{Literature Cited}

Ahn, J.K., W.W. Collins, and D.M. Pharr. 1980. Influence of preharvest temperature and flooding on sweet potato roots in storage. HortScience 15(3):261-263.

Collins, W. and G. Wilson. 1988. Reaction of sweet potatoes to flooding. HortScience 23(6): 1079

Kushman, L.J., M.T. Deonier, J.M. Lutz, and W. Bolton. 1954. Effects of temperature and soil moisture at harvest and of delay in curing on keeping quality of Porto Rico sweet potatoes. Proc. Amer. Soc. Hort. Sci. 63:415-419.

Kushman, L.J., M.T. Deonier, J.M. Lutz, and W. Bolton. 1958. Effect of weather, date of harvest, and curing treatments on keeping qualities of Porto Rico sweet potatoes. Proc. Amer. Soc. Hort. Sci. 71:369-375.

Kushman, L.J., M.T. Deonier, J.M. Lutz, and W. Bolton. 1959. Relation of internal gas content and respiration to keeping quality of Porto Rico sweet potatoes. Proc. Amer. Soc. Hort. Sci. 74:622-641.

Ton, C.S. and T.P. Hernandez. 1978. Wet soil stress effects on sweet potatoes. J. Amer. Soc. Hort. Sci. 103(5):600-603. 